\title{
APPLICATIONS OF SINGLE MINUTE EXCHANGE OF DIE IN INDIAN INDUSTRIES: LITERATURE REVIEW
}

\author{
Mukesh Shyamkant Desai* \\ Department of Mechanical Engineering, \\ National Institute of Technology Raipur, Chhattisgarh, India \\ A. M. Rawani \\ Director and Professor, Department of Mechanical Engineering, \\ National Institute of Technology Raipur, Chhattisgarh, India

\section{M.I.M. Loya} \\ Department of Mechanical Engineering, \\ National Institute of Technology Raipur, Chhattisgarh, India \\ *Corresponding Author Email: mukeshsdesai@gmail.com
}

\begin{abstract}
The main objective of this paper is to find out the various applications of Single Minute Exchange of Die (SMED) in Indian industries. SMED is a theory and set of techniques that make it possible to perform equipment setup and changeover operations within 10 minutes. SMED was developed by Dr. Shigeo Shingo in Japan. Several researchers, explained various applications of SMED likes in press machine shop, automobile industry, PVC manufacturing industry, crankshaft manufacturing industry, stamping industry, welding industry, Small Scale Industry, CNC manufacturing industry, injection molding machine in packaging industry, punching machine in gear manufacturing industry, steel industry, machine tool industry, diesel engine manufacturing industry, shaping machine in gear manufacturing industry, garment industry, bearing manufacturing industry, forging industry, CNC shaping industry, radiator, compressor and HVAC manufacturing industry, Diesel injection systems. The search process was focused on research papers, from various journals through a different electronic database. The total of 49 research papers is reviewed from various journals. In this paper, an attempt has been made to state, the various applications of SMED in Indian industries. After the findings various applications of SMED it is concluded that SMED is a versatile technique which is suitable for any industry to reduce setup time and change over time.
\end{abstract}

Key words: Changeover, Internal setup, External setup, Setup Time Reduction, Single Minute Exchange of Die (SMED). 
Cite this Article: Mukesh Shyamkant Desai, A.M. Rawani, M.I.M. Loya, Applications of Single Minute Exchange of Die in Indian Industries: Literature Review, International Journal of Production Technology and Management (IJPTM), 10(2), 2019, pp. 1-8. http://iaeme.com/Home/issue/IJPTM?Volume=10\&Issue=2

\section{INTRODUCTION}

Single Minute Exchange of Die (SMED) is one of the important lean tools, to reduce waste and improve the productivity of the manufacturing processes by reducing setup time and change over time, allowing lot size reduction and manufacturing flow improvements. SMED reduces the non-productive time by streamlining and standardizing the operations for exchange tools. (Alves, 2009). The core idea of the SMED is to reduce, the time which were wasted in many activities of the setup while the equipment's and machine runs as much as possible, and to simplify, streamline the remaining steps making the production flow more smoothly (Shingo, 1985; Patel et al., 2001; Samuel et al., 2001). Shingo divides the setup operation into two parts: Internal setup and External setup. Internal setup is that setup operation, which performs only when the machine is shut down (attaching or removing of the die). External setup is that setup operation, which performs when the machine is running. These operations can be performed either before or after the machine is shut down. For example, getting the equipment ready for the setup operation before the machine is shut down. (Shingo, 1985; Patel et al., 2001). The conventional SMED as proposed by Shingo is described by the framework shown in Figure 1. It consists of four different phases these phases are described as follows. (Shingo, 1985; Almomani et al., 2012).

\subsection{Phase 1. Current setup process map}

In this phase, the internal setup and external setup are mixed. It consists of observations of the ongoing process of setup and interactions with the operators about the operation/activities he is doing this help in the analysis of the current process (Shingo, 1985) A continuous production analysis performed with a stopwatch, The then to study actual conditions on the shop floor by interviewing workers. An even better method is to videotape the entire setup operations. This is extremely effective, if the videotape is shown to the workers immediately after the setup has been completed. (Shingo, 1985; Patel et al., 2001).

\subsection{Phase 2. Separate internal from external setups}

This is the most important phase in the implementation of SMED (Shingo, 1985). In this phase, preparation of parts, maintenance and so forth should not be done while machines are stopped. It should be done parallel which machines are in running conditions that means no effect on production. In this phase, the setup time can be reduced by $35 \%$ to $55 \%$ (Shingo, 1985; Alves, 2009; Almomani et al., 2012).

\subsection{Phase 3. Transferring internal to external setup}

In this phase, internal setups are possible to convert into the external setup (Shingo,1985; Goubergen et al., 2000). Implementation of this phase involves the following important notions:

- Re-examine the operations, to see whether any steps are wrongly assumed to be internal.

- Finding ways to convert these steps to external setup.

- Preparing operating conditions in advance: there are activities that, can be prepared in advance, allowing a reduction in the time of exchange of tools, for example: preheating machine parts or material to outside of the machine. (Shingo, 1985; Goubergen et al., 2000).। 


\subsection{Phase 4. Streamlining all setup operations}

After going through phase 2 (Separate internal from external setup) and phase 3 (Transferring internal to external setup), you can proceed to make sweeping improvement in elemental setup operations. (Shingo, 1985; Goubergen et al., 2000; Patel et al., 2001).

The techniques presented below help to achieve these improvements.

- Improvement in external setups: include streamline the storage, transport of components, tools and accessories, etc.

- The analysis of setup procedures helps the operator to execute their tasks in a better way, avoiding unnecessary physical movement.

- Improvement in internal setups: the improvement made in these operations produces significant reductions in changeover time.

- These improvements may be an execution of parallel operations, elimination of functional adjustments and fasteners.

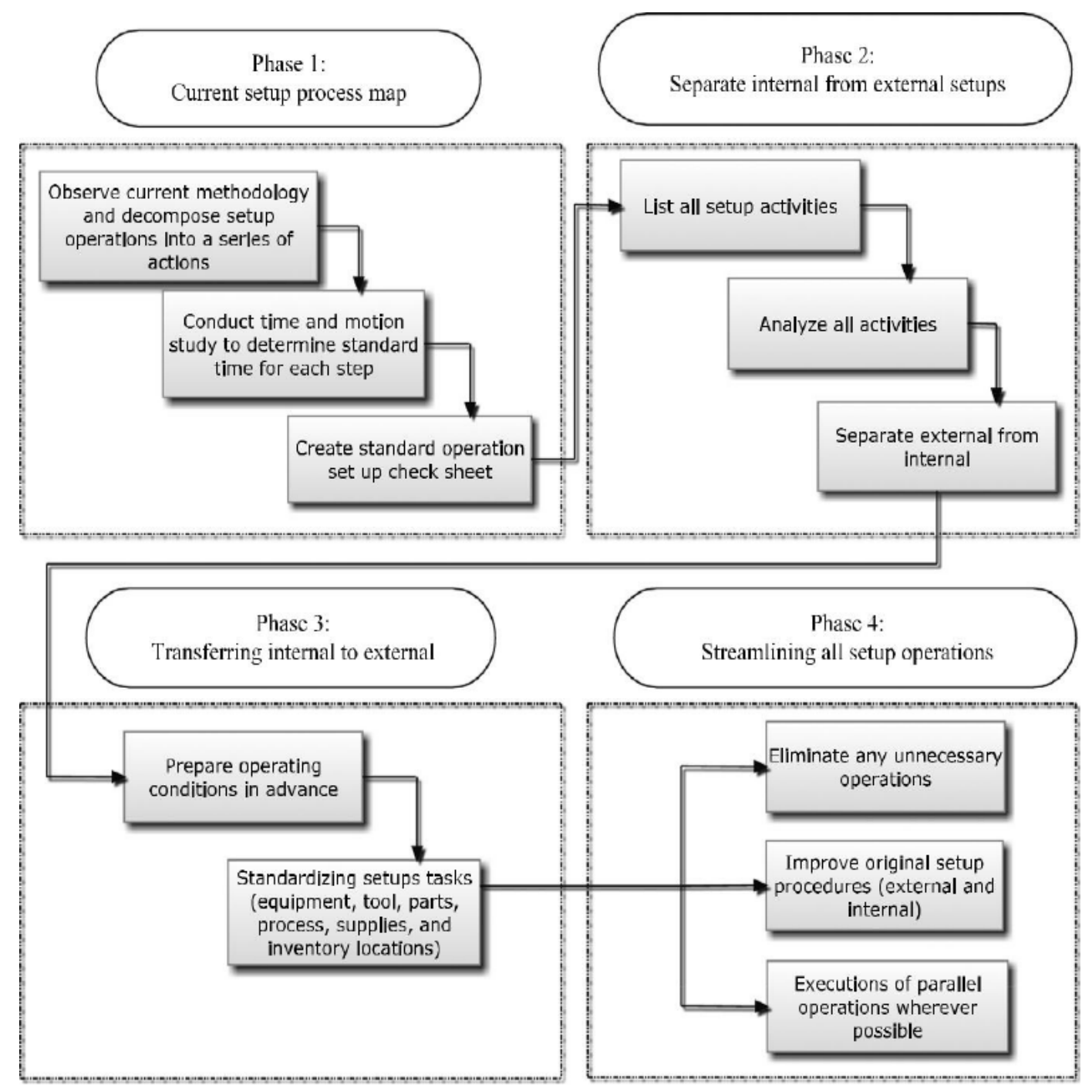

Figure 1 SMED conceptual phases and practical techniques (Almomani et al., 2012; Shingo, 1985). 


\section{LITERATURE REVIEW}

\subsection{Applications of Single Minute Exchange of Die}

The SMED methodology along with ECRS (Eliminate, Combine, Reduce, and Simplify) concept was adopted to achieve a reduction in setup change time (Pawar et. al., 2014). The Setup activities are a vital part of the production lead-time and so affect overall product cost. Tools like Pareto analysis, root- cause analysis and method study has been used to analyze the existing procedure of set-ups. Hence, reduction in average set-up time is reduced from 108 minutes to less than 16 minutes (Timasani et. al., 2011). Setup time reduction in a small factory involved in the machining of precision components in small batches with a large variety for the automobile industry implementation of conventional SMED the setup time is reduced by $82.44 \%$ and tool change time by $44.21 \%$. This helped to produce an additional 23 jobs/ shift with the same input (Desai and Rawani 2017). The applicability of the proposed SMED approach was tested for shaping machines changeovers in the automotive industry. (Desai, 2011). The setup time from 40 minutes to 12 minutes i.e. 28 minutes is reduced in a forging shop by using SMED technique (Suresh Kumar et. al., 2012). In BMS press for the production of hose clamps, set up time reduction and improved the productivity is increased from 60000 clamps/day to 105000 clamps/day (Abraham et. al., 2012). Setup time reduction through SMED with the integration of Planning System Interface, the validation of the proposed method was done through implementation on a manufacturing company which manufactures radiator and compressor (Palanisamy et. al., 2012). By implementing SMED, tool change time was reduced from 113.75 hours in June 2008 to 59.75 hours (Patel, 2013). The utilization of the synergic potential of SMED and Kaizen techniques. Roll changeover time in an Indian steel pipe manufacturing plant, is reduced by 32 percent (Ghosh et. al., 2013). Carried out an experiment to reduce the setup time in an automobile factory, the implementation of SMED on the setup process, is reduced the total set up time for the axle grinder from an initial time of 24.065 minutes to 14.416 minutes (a saving of $58.3 \%$ of time) increasing productivity by $65.38 \%$ per month calculated at 1500 setups in a month with an economic gain to the extent of 53\% (Adanna et. al., 2013). SMED methodology used for the reduction of changeover time in the garment manufacturing industry (Bajpai, 2014). The SMED methodology and other Lean Production tools (5S, Visual Management, Kaizen and Standard Work) were applied to reduce the setup time. As a result, the process setup time was significantly lowered from 52 to 24 minutes. The percentage reduction in the set-up time of $53.85 \%$ (Shinde et. al., 2014). The setup time reduction for CNC hobbing machine has been done by implementing SMED technique, optimal crane operation and by incorporating the design of the split fixture. The execution of SMED has successfully managed to reduce 02 hours 28 minutes and 30 seconds of setup time per day. (Sharma, et. al., 2014). By implementation of SMED in the bar rod mill II at Jindal Steel Work Vijayanagar. The reduction of pass change time by $21.34 \%$ after changing some of the internal activities to external activities and proper streamlining of activities (Gandhi et. al., 2016). Using SMED methodology the lead time is drastically reduced from 26.2 minutes to 20.9 minutes, therefore, the production rate has been increased from 480 products/day to 510 products/day at gear manufacturing industry. (Karthik et. al., 2016). By using SMED the oil filling process gets easier and as well as the time also gets reduced for filling the oil, time saved by 8-9 minutes (Gade et. al., 2016). 


\section{CLASSIFICATION FRAMEWORK TO SUMMARIZED THE REVIEW}

Table 1 shows the applications of SMED in Indian manufacturing industries. The search process was focused on research papers, from various journals through a different electronic database. The total of 49 research papers is reviewed from various journals.

Table 1 Applications of SMED in Indian Manufacturing Industries.

\begin{tabular}{|c|c|c|c|c|c|c|c|c|c|c|c|c|}
\hline Sr.No & $\begin{array}{l}\text { Name of } \\
\text { Industry }\end{array}$ & 2010 & 2011 & 2012 & 2013 & 2014 & 2015 & 2016 & 2017 & 2018 & 2019 & $\begin{array}{c}\text { Grand } \\
\text { Total }\end{array}$ \\
\hline 1 & $\begin{array}{c}\text { Gear } \\
\text { manufacturing } \\
\text { industry }\end{array}$ & & 1 & 2 & & & & 1 & & & & 4 \\
\hline 2 & $\begin{array}{l}\text { Automobile } \\
\text { industry }\end{array}$ & & & 3 & & 1 & 2 & 1 & 2 & 2 & 1 & 12 \\
\hline 3 & $\begin{array}{l}\text { Diesel engine } \\
\text { manufacturing } \\
\text { industry }\end{array}$ & & & 1 & & & & & & & & 1 \\
\hline 4 & Press Shop & & & 1 & & & & & 1 & 1 & 1 & 4 \\
\hline 5 & $\begin{array}{c}\text { Machine } \\
\text { manufacturing } \\
\text { industry }\end{array}$ & & & 2 & & & & & & & & 2 \\
\hline 6 & $\begin{array}{l}\text { Compressor } \\
\text { and air } \\
\text { conditioner } \\
\text { manufacturing } \\
\text { industry } \\
\end{array}$ & & & & 1 & & & & & & & 1 \\
\hline 7 & $\begin{array}{c}\text { PVC } \\
\text { manufacturing } \\
\text { industry }\end{array}$ & & & & 1 & & & & 1 & & & 2 \\
\hline 8 & Steel industry & & & & 1 & & & & & & & 1 \\
\hline 9 & $\begin{array}{l}\text { Crankshaft } \\
\text { manufacturing } \\
\text { industry }\end{array}$ & & & & 1 & & & & & & & 1 \\
\hline 10 & $\begin{array}{c}\text { Stamping } \\
\text { industry }\end{array}$ & & & & 1 & & & & & & & 1 \\
\hline 11 & $\begin{array}{c}\text { Small scale } \\
\text { industry }\end{array}$ & & & & 2 & & & 1 & & & & 3 \\
\hline 12 & $\begin{array}{l}\text { Garment } \\
\text { industry }\end{array}$ & & & & & 1 & & & & & & 1 \\
\hline 13 & $\begin{array}{l}\text { Forging } \\
\text { industry }\end{array}$ & 1 & & & & 1 & & & & & & 2 \\
\hline 14 & $\begin{array}{c}\text { Steel Pipe } \\
\text { manufacturing } \\
\text { industry }\end{array}$ & & & & 1 & & & & & & & 1 \\
\hline 15 & $\begin{array}{c}\text { Footwear } \\
\text { manufacturing } \\
\text { industry }\end{array}$ & & & & 1 & & & & & & & 1 \\
\hline 16 & $\begin{array}{c}\text { Bearing } \\
\text { manufacturing } \\
\text { industry }\end{array}$ & & & & & 1 & 1 & & & & & 2 \\
\hline 17 & $\begin{array}{l}\text { Injection } \\
\text { molding } \\
\text { industry }\end{array}$ & & & & & & 1 & & 1 & 1 & & 3 \\
\hline 18 & $\begin{array}{l}\text { Machine tool } \\
\text { manufacturing } \\
\text { industry }\end{array}$ & & & & & & & & & 1 & 1 & 2 \\
\hline 19 & $\begin{array}{l}\text { CNC machine } \\
\text { manufacturing } \\
\text { industry }\end{array}$ & & 1 & & & & 1 & & & & & 2 \\
\hline 20 & $\begin{array}{c}\text { Foundry/ } \\
\text { Casting Shop }\end{array}$ & & & & & & & & 1 & 1 & & 2 \\
\hline 21 & $\begin{array}{c}\text { Corrugated } \\
\text { Cardboard box } \\
\text { manufacturing } \\
\text { company }\end{array}$ & & & & & & & 1 & & & & 1 \\
\hline & Total & 1 & 2 & 9 & 9 & 4 & 5 & 4 & 6 & 6 & 3* & 49 \\
\hline
\end{tabular}


The table 1 shows that, various applications of SMED in Indian manufacturing industries. It also clear that awareness about SMED Methodology has been increased in the Indian manufacturing industries and SMED is a versatile technique which can be useful in any industry.

\section{CONCLUSIONS}

This study described applications of the SMED methodology in Indian manufacturing industries. After study the literature we, came across the following conclusions. SMED is a versatile technique which is suitable for any manufacturing industry to reduce setup time and change over time. Literature also resulted in that; SMED can be combined with other lean tools and optimization techniques such as 5S, visual control, Kaizen, Analytical Hierarchy Process (AHP), Preference Selection Index (PSI). SMED successfully implemented in various manufacturing industries but, a search of the literature did not results/shows any article in service industries like hotel industries, health care services (hospitals), transportation and telecommunication industries.

\section{REFERENCES}

[1] Abraham, Aru., Ganapathi, K. N. and Motwani, Kailash. "Setup Time Reduction through SMED Technique in a Stamping Production Line", SAS Tech Journal, Vol. 11, Issue 2, 2012.

[2] Adanna, I. W. and A. Shantharam. "Improvement of Setup Time and Production Output with the use of Single Minute Exchange of Die Principles", International Journal of Engineering Research, Vol. 2, Issue 4, 2013.

[3] Almomani, Mohammed Ali., Academy, Mohammed., Abdelhadi Abdelhakim. and Mumani Ahmad."A proposed approach for setup time reduction through integrating conventional SMED method with multiple criteria decision-making techniques", International Journal of Computers and Industrial Engineering, 66, 2012, pp.461-469.

[4] Alves, Ana Sofia. "Improving SMED in the Automotive Industry: a Case study", POMS 20th Annual Conference Orlando, Florid U.S.A. 2009.

[5] B, Suresh Kumar, and Abuthakeer, S. Synth. "Productivity Enhancement by Implementing Lean Tools and Techniques in an automobile Industry", International Journal of Engineering Annals of faculty Engineering, Hunedoara, Vol. 10, Issue 1, 2012.

[6] Baishya, Nystha. and Rao, Satish U. "Applying SMED/QCO Tool to Improve the Productivity at Screwing Station of HFR Assembly a Study at Robert Bosch (India) Limited", International Journal of Mechanical and Industrial Engineering Development and Research, Vol. 3, Issue 1, 2013.

[7] Bajpai, Jonalee D. "Single Minute Exchange of Die Methodology in Garment Manufacturing Industry: Case Study in Reducing Style Change over Time", $5^{\text {th }}$ International and $26^{\text {th }}$ All India Manufacturing Technology, design and Research Conference, IIT Guwahati, Assam, India, 2014.

[8] Dave, Yash. and Sohani, Nagendra. "Single Minute Exchange of Die Methodology: a Literature review", International Journal of Lean Thinking, Vol. 3, Issue 2, 2012.

[9] Desai, M. S. and Warkhedkar, R. M. "Productivity enhancement by reducing adjustment time and setup change". International Journal of Mechanical and Industrial Engineering, Vol. 1, Issue 1, 2011.

[10] Desai, M. S. "Productivity Enhancement by Reducing Setup Time - SMED: a Case study in the Automobile factory", Global Journal of Researches in Engineering Mechanical and Mechanics Engineering, Vol. 12, Issue 5, Version 1, 2012. 
[11] Desai, Mukesh., Rawani, A. M. "Productivity Improvement of Shaping Division of an Automobile Industry by Using Single Minute Exchange of Die (SMED) Methodology" ARPN Journal of Engineering and Applied Sciences. ISSN 1819-6608 Vol. - 12, No.-08, 2017, Page-2615-2629.

[12] Gandhi, M K., and Singh, Aman Kumar. "Reduction of Setup Time by Implementation of SMED Methodology", Imperial Journal of Interdisciplinary Research, Vol. 2, Issue 9, 2016.

[13] Gade, Pallavi A., Chavan, Roshan G. and Bhavsar, Dhananjay N. "Reduction in Setup Time by using Single Minute Exchange of Die (SMED) Methodology", International Journal of Science and Technology Research, Vol. 5, Issue 06, 2016.

[14] Goubergen, Dirk Van., and Landeghem, Hendrik Van. "A Quantitative Approach for SetUp Reduction of Machine Line", Production and Inventory Management Journal 31, 2016, pp. 55-59.

[15] Garg, Gaurav., Gupta, Ajay., More, Rahul S. and Trehan, Rajiv. "Execution of single minute exchange of dying on corrugation machine in cardboard box manufacturing company: a case study", International Journal of Lean Enterprise Research, Vol. 2, Issue 02, 2016.

[16] Ghosh, S., Chaudhury, P. K., Pramanik, D. and Lal, S. "Changeover Time and Its Variability Reduction through SMED - Kaizen Approach: Case Study of an Indian Steel Pipe Manufacturing Unit”, Proceedings of ICIE NIT Surat, India. 2013.

[17] Singh, Jagdeep., Singh, Harwinder., and Singh, Inderdeep. "SMED for the quick changeover in the manufacturing industry - a case study", Benchmarking: An International Journal of Production and Operation Research, Vol. 25 Issue: 7, pp.20652088, https://doi.org/10.1108/BIJ-05-2017-0122, 2018.

[18] Kelkar, Mandar A., Shekapure, Nitin G. and Kallurkar, Sachin S.“Optimization of setup Time Reduction for Flexible Manufacturing System”, Proceedings of ICIE NIT Surat, India. 2013.

[19] Karthik, N., Prasad, Hari. and Gopi, Balaji. "Application of Lean Tools (VSM, SMED, Kaizen) In Minimizing the Lead Time in Gear Manufacturing Process", International Journal of Scientific \& Engineering Research, Vol. 7, Issue 5. 2016.

[20] Mistry, Pankajkumar. J. and Desai, Mukesh. "Set up Change Time Optimization Using Single Minute Exchange of Die (SMED) Methodology", International Journal of Research in Electronics and Communication Technology, Vol. 2, Issue 1. 2015.

[21] Mandwe, Priti. "Productivity Improvement of Crankshaft", International Journal of Science and Technology Research, Vol. 2, Issue 7, 2012.

[22] Palanisamy, S., and Siddiqui, Salman. "Changeover Time Reduction and Productivity Improvement by Integrating Conventional SMED Method with Implementation of MES for Better Production Planning and Control", International Journal of Innovative Research in Science, Engineering and Technology. Vol. 2, Issue 12. 2013.

[23] Patel, Chintan Kumar. "Setup Time Reduction. A Perfect Way for Productivity Improvement of Computer Numerical Control (CNC) Setup in Manufacturing Company", International Journal of Mechanical Engineering Research, Vol. 5. 2013.

[24] Pawar, Gaurav J., Sirdeshpande, Nishant S., and Patil, Rachi. "Reduction in Setup Change Time of a Machine in a Bearing Manufacturing Plant Using SMED \& ECRS, International Journal of Engineering Research. Vol. 3, Issue 5. 2014.

[25] R, Bharath., and A, C. Lokesh. "Lead Time Reduction of Component Manufacturing Through Quick Changeover (QCO)", SAS Tech, Vol. 7, Issue 2, 2008.

[26] Raikar, Nagaraj A. "Reduction in Setup Time by SMED Methodology: A Case Study", International Journal of Latest Trends in Engineering and Technology, Vol.5, Issue 4, 2015. 
[27] Rao, Sunish., Yadav Rohit., Ranade Shreyas., and Waste Prasad. "Application of SMED in Rim Manufacturing Plant for Light Motor Vehicle", International Journal of Science Technology and Engineering. Vol. 2, Issue 11. 2016.

[28] Samuel, Jebaraj Benjamin., Uthayakumar Murugaiah., and M. Srikamaladevi Marathamuthu. "The use of SMED to eliminate small stops in a manufacturing firm", Journal of Manufacturing Technology Management, Vol. 24 No. 5, 2013 pp. 792-807

[29] Singo, Shingo. "A Revolution in Manufacturing: The SMED System". Productivity Press, Cambridge, MA. 1985.

[30] Singo, Shingo. "Zero Quality Control: Source Inspection and the Poka-Yoke System". Productivity Press, Cambridge, MA.1989.

[31] Shinde, Shashikant., Jahagirdar, Satyasheel. and Sane, Shriram. "Set-up Time Reduction of a Manufacturing Line Using SMED Technique", International Journal of Advance Industrial Engineering. Vol. 2, Issue 2. 2014.

[32] Singh, Bikram Jit and Khanduja Dinesh. "SMED: for quick changeovers in foundry SMEs", International Journal of Productivity and Performance Management, Vol. 59 Iss 1, (2009). pp. 98 - 116. Permanent link to this document:

[33] Singh, Jaskaran and Singh Gurinder. "Process Improvement and Setup Time Reduction in Manufacturing Industry: A Case Study" International Journal of Advances in Mechanical Research, 9(1) 2018, January-June, 2019, pp. 15-23.

[34] Surabhi Lata, and Sharma Kshitij Mohan. "Implementation of Lean Thinking in Manufacturing and Non-Manufacturing Sectors: A Review", International Journal of Lean Thinking, Vol. 8, Issue 2, 2017

[35] Shobha. N.S, and Subramanya K.N. "Simulation of Kanban System in an Automobile Component Manufacturing Organization - A Case Study", International Journal of Lean Thinking, Vol. 9, Issue 1, 2019.

[36] Timasani, Ramesh., N.S. Mahesh. and Doss, Kishan. "Reducing the Setup Time in a CNC Machining Line Using QCO Methods", SAS Tech Journal, Vol. 10, Issue 2, 2011. 